\title{
Nikolai Gogol's Literary Works, Tsar's Absolutism and Russian Cutural Life in the 19th Century: A Preliminary Note
}

\author{
Herdi Sahrasad $^{1}$, Muhammad Ridwan ${ }^{2}$ \\ ${ }^{1}$ Senior Lecturer in University of Paramadina, Jakarta, Indonesia \\ ${ }^{1}$ Lecturer in University of Muhammadiyah Jakarta, Indonesia \\ ${ }^{1}$ Senior Fellow in Centre for Strategic Studies University of Indonesia (CSS-UI), Jakarta, Indonesia \\ ${ }^{2}$ Lecturer in State Islamic University of North Sumatera (UINSU), Medan, Indonesia \\ Email:sahrasad@yahoo.com
}

\begin{abstract}
This paper is to study and understand the work of Nikolai Gogol, and to learn what and to what extent Tsar's absolutism in Russia under the old regime, has influenced his work, as well as its impact on the social, cultural, political, and economic realities of Russia under the Emperor's powerful rule in 19th century. Here also revealed, to what extent the tragic human life in Gogol's work and how the efforts of the author to uphold the existence and dignity of themselves and their society are revealed in the story "TarasBulba" and examine the tragic human life that experiences injustice and dehumanization, which is revealed in the story "Shinel " (Baju Mantelor Coat Dress). It is important to be able to learn and understand what and to what extent Gogol's role in the literary and cultural life of Russia in his day, especially regarding his influence in Russian literature and the values of Gogol's universal humanism for the life and culture of human being in this Earth.
\end{abstract}

Keywords: Gogol; Shinel; TarasBulba; Rusia; Tsar; absolutisme; autocrat; culture; literature

\section{Introduction}

In the 19th century Nikolai Gogol crossed out his literary work which was later called a brilliant work. Even many literary critics from Russia and not like Belinskiy, Tsjernisjewski Hans Kohn, Marc Slonim, De Jonge, and others said that the short stories and typical Russian prose perfectly came to Gogol. Does this statement contain truth? Does this reveal the literacy value? For the authors themselves this is still a mystery.

More than that, Gogol is also widely referred to as a defender of the oppressed and underdeveloped Russian society who wants justice. The link between his role as a writer and intellectual is very interesting to be studied. And the author believes this will not be finished, because his literary works have been eternal and relevant to the problems of our time. Gogol's novels, drama and romance have moral values for human history. So that his actual work is interesting to be examined, depending on the angle we look at. Why is that? Because the contents of Gogol's literature are life.Human life with its soul, mind, and feelings. Soul, mind, and feelings formed by the surroundings.

The style of Gogol's realism which blew new trends in Russian literature and the breath of naturalism that he exhaled in his work, is also interesting to study. And this is what I think is the historical value that makes him attractive to be traced through his work and background. Hans Kohn stated that literature in Russia in the 19th century was clearer in describing the confusion of humans who were not ready to accept modernization than Western literature. And Gogol is one of them, who plays a prominent role. His literary works revealed many tragedies, such as in "TarasBulba" and "Shinel" which became the study of this paper.

In the stories of "TarasBulba" and "Shinel", Nikolai Gogol reveals the tragic human life of his day. The story of "TarasBulba" is a story about the struggle of the Kozak man in driving away the occupation of the Turkish and Polish Tartars where the main character met his death, here the struggle of Mania was endless with tragedy. Whereas the story of "Shinel" reveals about the 
tragedy of man who during his life experienced injustice due to the abuse of power in the bureaucracy and government-in the Tsarist era.

The unlimited power of the Tsar, autocracy and authoritarianism has had a positive and negative impact. The positive impact was the presence of Russian military and technological modernization as a measure of the Tsar's political will. However, the negative impact is far greater because the westernization program and its modernization bring huge losses to the people down due to the many deviations carried out by the feodels and the bourgeoisie with special rights guaranteed by the king's power.

The Tsar's absolutism and autocracy invited opposing reactions from intellectuals, writers, the military and the oppressed people of the lower classes. Where Gogol is here, then the realism theory is to understand literature as a social commitment.

\section{Review of Literature}

\subsection{Leterary Art}

Literary art is the art of language. To understand and appreciate literature one must understand language. Language with all possible communication and aesthetic potential. Language itself is a tool of communication of ideas, emotions and human desires that are pure with a system that is deliberate to produce symbols (E. Sapir, 1949: 8). While Sartre once mentioned that: "the language is a structure of the external world. The speaker is a situation, in language, he is invested with words ..." (Sartre, 1949: 13).

On the other hand, Barthes said that all types of social communication systems are languages and to avoid obscurity he uses the term code. And according to him, all social codes like language, have vocabulary.

Until here it is clear that language is the medium of thought, emotion and the human soul as a system of social communication. Then, what is literature? Lotman has called it a sign system because humans are, "maker and reader of signs" (A. Teeuw, 1983: 6). Likewise Saussure (Scholes, 1976: 2). Although literature is synonymous with language, there are differences between languages in everyday language literature. In art (literature) language is processed in such a way systematically and deliberately so that the creator's personal appearance appears, "that literary language is first of all varied uses of every day. The resources of language are exploited much more deliberately and systematically. In the work of a subjective poet, we have manifest a personality far more coherent $\because$ (Wellek and Warren, 1956; 24).

\subsection{Literature}

Literature is an area where the process of creativity is accepted and fostered as the main task and virtue. Literature is an area where the creation process takes place (IgnasKleden, 1981: 75). Art (literature) is already a reflection of the aesthetic experience, the soul and the senses of its creator. That artists according to Susanne K. Langer, in creating art, have contemplated and felt that direct experience and made it a common experience and can be digested by others (S.K.Langer, 1982: 75 in M. Sastrapratedja, 1982). Thus, literature is the result of creativity in the form of a complete roundness, distinctive and independent. It is a world of beauty in the form of language which from its own essence has been filled with life and reality. 


\section{Metodology}

In this study, the author uses the methodology of genetic structuralism. However, before describing the method, the author will first describe what the essence of literature, literary criticism, approaches to literary works and matters relevant to literature and finally about genetic structuralism itself.

\section{Discussion}

\subsection{Gogol and His Two Novels}

The weighty literary works always tend to be multi-dimensional and multy-interpretable, especially works that have good quality. Such literary works generally also tend to stimulate readers. The reader is challenged to grapple with what is implied in the work, to seize its meaning within the limits of his sensitivity and skill. Therefore, it is not surprising that literary activities contain risks, namely succeeding or not seizing their meaning, reaching its essence. If successful, it might get satisfaction, otherwise if it is not possible to get disappointment.

The two novels by Nikolai Vasilevic Gogol each titled "TarasBulba" and "Shinel", for instance. attracted the attention of the author to study them. This novel was written by the author in the 19th century, which one. If we study the history of Russian literature, it will be reflected in it a breath of realism. We can understand this because at that time Central Russiaexperiencing the process of westernization and modernization symbolized by the Western architectural and technical style of the city of St. Petersburg on the one hand, while on the other hand, farmers and slaves lived in poverty and underdevelopment in the way of Eastern culture. From existencethis conflict arose dualism in Russian consciousness. The Russian Earth embraces two conflicting worlds: the one world of St. Petersburg is characterized by the West, with the culture of Western society, Western bureaucratic and military order. Another world is the world of peasants, traders and religious people. The development of this dualism is increasingly becoming more and morelifting up the ruling class and sinking down under the mastered class. Here according to WiratmoSoekito the conflict began to arise and was inevitable (W. Soekito, 1959: 32).

In reality, this is what emerges later intellectuals and writers who are aware of the conditions of social, cultural, political and economic life in their environment. They consciously and dare to try to express the turmoil of their thoughts, feelings and souls. As a reaction to that sad reality so that their works are not born of vacuum, social emptiness, but are a true portrayal of life, at least approachingthe real life. And in other words, literature encompasses all life that might be experienced by a conviction (HB. Jassin, 1952: 10).

Certainly no story revealed by the literary in his work is the result of reflection on the entire contents of life, but: "the essence, the abridgement and summary of all history" (Wellek and Warren, 1956: 95). In this case, surely the essence and historical summary relating to the process of westernization and modernization that took place in Russia since the reign of Peter the Great (Peter the Great), which turned out to be followed by an absolute power system, a merciless system of iron hands which would later be continued the successors. The implication of this autocratic and absolute power attitude is the separation of state and society, history is nothing more than an accumulation of Tsarist autocratic forces: "One of the characteristic features of Tsarist Russia was the separation of state and society ... The history of nineteenth century Russia is more than a history of autocratic power and its exercise ... "(M. Fainsod, 1958: 5).

So right what Mosca said following: "In elections, in all other manifestations of social life, those who have the will, especially, the moral, intellectual and material means they will upon others, take the lead over 
the others and their command "(Gaetano Mosca, 1959: 154). Thus, intellectuals, writers and philosophers as middle class with their will, their moral and intellectual strength, tried hard to lead the people against the Tsarist tyranny, the autocrats. The writers here are not only involved in physical struggle in real life, in their works they also see new perspectives on the development of specific Russian national history, national character of the Russian people, "raskereivaetnatsionalnuyuspesijfikurusskoiistoritseskoidjzizni, nasjionalneiharakterrusskowonaroda." (Blagoi, 1963: 6).

Chernyshevsky and Belinsky also emphasized that Gogol always gave an overview of the Russian social reality of his day so that his work was characterized by realism (M.Slonim, 1958: 71-79). The reason why his work is a statement of the spirit of nationality that developed historically, dialectic rather than political and economic ideas, which realized the importance of realism and social conditions, (SapardiDjokoDamono, 1979: 29-30). Until now, it appears that Gogol tends to try to find a contextual relationship between literature and life, in which Gogol's works have social commitment in literature.

\subsection{Tsar Absolutism}

Before coming to the discussion of the impact of Tsar absolutism on Russia's social, cultural, political and economic realities in the nineteenth century, the author will first describe the notions and limits of absolutism.

'Absolutism' in the Indonesian Encyclopaedia is defined as the form of administration of power and government in the state, whose power and obligations are centered in the king (1980: 63). Therefore the shape of the country is monarchy. The monarchy itself is a form of government in which power is in the hands of individuals who have the right to rule for generations and remain in office for the rest of their lives, as implied in this quote, "Monarchy: form of government in which sovereignty is vested in a single person whose right to rule is generally hereditary and who is empowered to remain in office for life "(The New Columbia Encyclopedia, 1975: 1809).

If the king in power rules in absolute terms, then the government is called a despotic government. The notion of despotism itself according to The New Columbia Encyclopedia is as follows, "despotism: absolute government unchecked by effective constitutional limits to his power" (1975: 752)

From this quote 'despotism' can be interpreted as a form of government by a ruler the absolute without constitutional restrictions and effective control of his power. In other words, despotism is a form of government where a ruler rules without constitutional and arbitrary restrictions. With the understanding, and limitations above, the Tsarist system of Russian government can be classified into it. Even in the eyes of the Tsar, absolutism and the centralization of power were truly inseparable from the life of the country. Power is directed at serving the interests of the Tsar's autocracy, the commands of 'above' are obeyed and seen as the highest wisdom of the autocrats, "the directive authority was largely reserved for the representatives of the autocracy; their commandments were obeyed as the paternal expression of the supreme wisdom of the Autocrat "(M. Fainsod, 1958: 4-5).

This absolute power is not only limited to political and economic aspects, but also social and cultural. To support this, the Tsarist regime echoed the ideology which states that autocracy, Orthodox beliefs, superiority of nobility, obedience of ordinary people and the view of patriarchal life are the basic principles of the state, "The official ideology of the autocracy, Orthodox religion, the superiority of nobility, the mute obedience of the lower classes, and the patriarchal way of life the firm foundations of the State "(Marc Slonim, 1958: 71). 
The signs of Tsar absolutism can be seen from the following variables:

1. Centralized power to the king with justification by the king himself and his followers.

2. Without constitutional and arbitrary restrictions.

3. Very sensitive to centrifugal movements, whatever the purpose.

4. Maintaining a conservative, oligarchic and monopolistic attitude despite knowing that this is not true.

5. Directing power for the benefit of the ruler

\subsection{Implications of TsarAbsolutism in Russia}

In its historical process, Russia until the beginning of the 20th century was ruled by an autocratic and feudalistic Tsar. During the reign of Peter the Great began the process of westernizing Russia which moved slowly during the 18th century. The city of St. Petersburg became a symbol of the modernization, the world was a New world with Western culture, Western engineering and architecture. bureaucratic order and Western militarism. While on the other hand, there still appears to be a lower society life characterized by poverty and backwardness, an Old world symbol.

Peter the Great tried to build Russian culture secularly. He acted as a tyrannical and ambivalent king as stated by Slonim: "To carry out vast designs, he acted as a tyrant and resorted to force and violence and here lies on the character of his reign, on the one side, reforms, and on the other, the greater burden of suffering on the people "(Marc Slonim, 1958: 15-16).

Peter the Great also strives to build a modern bureaucratic organization to improve efficiency and effectiveness. But the results are not satisfactory even almost in vain. Bureaucracy is actually inefficient and ineffective, "The dominating role of authority is that it is highly centralized but far from efficient bureaucracy .... The duty of the people is to serve the Autocrat by yielding implicit obedience to his dictates "(M.Fainsod, 1958: 4).

This westernization process has resulted in the entry of the capitalist class into Russian territory, initially affecting cities where Western influence can enter and expand (Favtov G., 1976; 18).

Meanwhile in the villages there has long been a emergence of the local bourgeoisie (kulak) which also continues to exploit poor farmers and slaves so that the lower classes of society experience a fatal process of impoverishment (Favtov G., 1976: 18).

The process of impoverishment of the lower layers of society is getting heavier after the local bourgeoisie (rich peasants or kulaks) and feudals (nobles) are both monopolistic and exploit them (Djziharev N.A., 1976: 44). Such bitter facts repeatedly resulted in the rebellion against the ruler and the bourgeoisie and the capitalist.

Both Peter the Great and his successors, the Russian system of government has not changed much. The imprinting characteristic is autocratic, bureaucratic and modeled. In the time of Alexander I, it could be said that the problems of the state were in chaos. Abuse of power and embezzlement is everywhere. The government bureaucracy is very chaotic and rigid. Order seems to have disappeared, but even so, the state only tends to expand its territory.

Alexander I did not succeed in eroding absolutism as what he had dreamed of. Even in his day individual rights and freedoms thought nothing at all. Symptoms of corruption and militarism swelled up in the period of the administration of this ruler. Not only that, slavery expanded as before. He left Russia in a sad state (Hans Kohn, 1957 : 8-9). The westernization policy that has been carried out since the time of Peter the Great still has inevitably had a 
negative impact, "which led to the triumph of capitalist economic forms and in this shape had been unknown in Russia"(G.Von Rauch, 1957: 5)

After Alexander 1 died, Nikolai I came to power. The Nikolai I government was characterized by militarism. The step towards modern industrialization continues. He also tried to create an intermediate group which was expected to function as an intermediary for the upper class and lower class. But all that is of little use to the people below. He did not take much effort to find solutions to Russia's social and cultural problems. In reality, the problem of slavery by landlords remained unresolved.

Tsar Nikolai's power was also no different from the previous Tsar which was absolute and autocratic, the church which was very orthodox and slavery of peasants was seen as strong foundations for his country. In the midst of social and cultural realities that are very contradictory due to the existence of modern patterns of life oriented to the West and traditional patterns of Russian life that are patterned in the East a wide social gap between the rich (such as nobility, bourgeoisie, rich farmers) and oppressed (poor) like landless farmers, laborers and slaves; also the gap between cities and villages, then a radical revolutionary movement emerged. This revolutionary movement was pioneered by the military. This military uprising called for a constitution. This event occurred on December 14, 1825 and was quickly suppressed by the authorities. Then he recorded this event as a "December rebellion" by the "Jecabrists" (Blagoi, $1963 ; 16)$.

It is not surprising that cheating took place within the aristocracy towards the lower classes because they had special rights while the people were in an atmosphere of tense terror and apathy and pessimism. In short, the political impact of Westernization and modernization of Russian culture which began in the time of Peter the Great both in terms of social, cultural, political and economic aspects can be seen in its impact on the bureaucracy, the life of peasants/farmers (slaves), and Russian intellectual development in this period, the author's intent: from the period of Peter the Great's reign to Nikolai I where in this period the writer Nikolai Gogol appeared on the scene of modern Russian culture (1809-1852).

Although it must be admitted that the westernization process has brought progress to Russia, it is still not much compared to the losses that must be borne by the people, especially the lower classes. In this case, let us begin from the first, namely the impact of westernization and modernization of the bureaucracy.As we have seen, since the Great Peter was established, he ruled through the bureaucracy which eventually became an autocracy which was found in all aspects of the kingdom which had unlimited royal power, in all fields with absolute power, not monitored and not announced as well. this governs by way of royal ordinances that guarantee the implementation of royal police assistance. Nothing also limits the king to both the parliament and the court.

Law arbitrarily becomes a habit; the Tsar's will even had the power of law and the king's staff were only ordinary employees who did not have an accountability and often had no sense of greatness and courage. This bureaucracy has indeed made Russia a modern country. But his government was very hard and therefore corrupt and slow and very rigid, it was contrary to the new power of the liberal movement which was always growing. The Tsar's politics were bureaucratic politics, open political competition was replaced by disputes and closed bargaining between a private group of empires and a growing number of government bureaucracies. Officials who occupy their positions without going through elections, regardless of their level, region or function, can act as lords with or without going through electoral politics. Here bureaucracy means the opportunity to exercise authority (Keith R. Linde, 1983: 69). Thus the 
bureaucratic system does not only mean a great power of ability and degree of reach, but also means the ability to use that power arbitrarily.

Second, is the impact of westernization and modernization on the lives of farmers. Even though it has undergone a process of westernization and modernization, farmers' lives have not developed. They are a proletarian village, destitute and underdeveloped. Whereas the great landlords continued to rule (Jean Bruhat, 1954: 8).

The peasants/farmers are forced to be diligent and obedient to their master. For all the mistakes made by slave farmers against their owners, these rich landlords often do whatever they want and even they can summon police or royal soldiers to help carry out their powers. Farmers do not have legal protection to deal with abuse of power and oppression by landowners (rich farmers / kulaks). It is ironic and contradictory, Russia, which is undergoing a process of westernization and modernization, is still behind its civilization. Over the years the law has not provided slave farmers with the tools to fight the arbitrariness and injustice of their employers.

The government only had the desire to protect them from this oppression, but in reality: it was very rare for the Tsar government to interfere with matters of problems between employers and farmers because of anxiety and fear that this would reduce the power of the owners and arouse feelings of opposition among the peasants. Thus the peasants really suffered under the rule of the Tsar. Cruel and inhuman treatment destroys the body and soul.

The slave farmers were not only exerted with energy and soul, the heavy taxes imposed on the owners against them. It is not strange if many farmers are not resistant to these barbaric and arbitrary acts, they rebel against their owners. To avoid this danger many owners lived in places far from their slaves. Generally live in the city. On the other hand, not being able to live as slaves in the village, many farmers in Pula "slave" into the city as laborers in industrial centers with low wages. This reminds us of the proletarian class in the West, which is exploited by the capitalists. So, "Until the economic development of the Russian Empire created industrial and labor problems ... and a proletariat of the western type ...".(I. Berlin, 1979: 3).

The proletarian people are rapidly increasing in number, they are increasingly disappointed, hurt and frustrated with the oppressive and unfair social structure. They are more intrigued by their thoughts and feelings towards the voices of intellectuals, and revolutionaries. Meanwhile their lives continued to get worse and the system of the Tsar's government became increasingly repressive and violent towards all voices who opposed its existence. As a result the dichotomy of slaves and landlords, rulers and the ruler, the haves and the have not are increasingly qualitative and quantitative as well as dichotomies between modern and traditional, city and village, development and under-development in Russia are increasingly evident. the third is the impact of modernization and the modernization of intellectual development.

The process of the Russian modernization and modernization by Peter the Great contains contradictory things. On the one hand, Russia has succeeded in building the army and technology to become a tough rival in the struggle for power in Europe. But on the other hand, the basics of society, intellectuals and economic life in Russia remain largely ancient and not affected by military developments and technology. Peter also founded a higher education institution. But the number of students at.this institution is very little compared to the population of Russia at that time. The tsar, the ruler, was hard-pressed so that most students the students came from noble families and only a small portion of them came from the lower classes of society, the sons and daughters of the Orthodox clergy. As a result, there are almost no, there are absolutely no students from ordinary people. 
The reaction to these problems can be divided into two groups. The first is the Western group, namely the liberal group who generally want to follow the examples given by Europe. The second is the Slavophils, namely the romantic nationalist group, who always glorify the greatness of the history of Russia that has passed and which upholds the things they consider to be the good of Russia which in their view is higher than the goodness of Europe which they consider rusty that.

Meanwhile, individual and social freedom still does not exist. The voices of intellectuals who long for the government to suppress social reform, restraints continue. Belinsky (18111848), one of the leaders of the Western class, said that Russian disease was actually rooted in the absence of human freedom to act or think. There is no individual freedom, so, "There was nowhere any sign of effective independent thought or action" (D.W. Treadgold, 1973: 1).

That is why Belinsky called for the art of commitment to the goals of society so that it can give birth to renewal (revolution): "that art must serve a social purpose, which broadly speaks of the cause of revolution" (Belinsky in D. W. Treadgold, 1973: 182).

Although intellectual life is very closely watched and limited and isolated from the backward general public, Intellectuals did not stop inviting the public to oppose the autocracy and absolutism of the ruler so that finally the autonomy of the university which had been restrained was completely eradicated, the teachers and students were supervised by their hardness, higher education was limited to those who could be trusted Orthodox.

That is why intellectuals try to hold radical movements that almost always try to create tshirts (chaos), namely by using violence, alliance with military or revolutionary youth. This kind of action is usually repaid by a very hard and indiscriminate slaughter or massacre of the authorities.

\section{Conclusion}

Of all the descriptions that the author has described above, it appears how hard and terrible the Russian social, cultural, political and economic conditions and conditions were during the period of Peter the Great to Nikolai I, during which time Nikolai Gogol appeared with a high degree of creativity. He also expressed the problematic social vocation of art and argued that the authors (writers) were obliged to devote themselves to the community. It is understood if Gogol's literary works are involved, "engaged", "committed". The existence of this "engagement" motive indicates that he wrote with the aim of establishing a relationship (communication) with other people. In the midst of the swamps of darkness and Russia's uncertainty at that time it was easy to understand Gogol's attitudes and statements conveyed and expressed in his above works.

\section{References}

Berlin, I. (1979). Russian Thinkers, U.S.A. : Pelican Books.

Belinsky, V.G. 1953, Polnoe Sobranie Socinenyie, SSSR : Akademia Nauk.

Blagoi, D.D., ed. (1963). Istoria Russkoi Literature Trioh To mah, Moskwa-Leningrad: Akademia Nauk SSSR

Bruhat, J. (1954). Sejarah Soviet Rusia, terjemahan Suwarsih Djojopuspito, Jakarta: Pustaka. Rakyat.

Djoko Damono, S. (1979). Sosiologi Sastra, Jakarta: Pusat Pembinaan dan Pengembangan Bahasa, Departemen P \& K.

De Jonge, A. (1973). Gogol, London: Oxford New College.

Donchin\&Anning, J.A. (1980). Russian Literary Attitudes From Pushkin to Solsynitsin, Great Britain. 
Djziharev, N.A. (1976). VelikayaOktyarkayaSotsialistices - kava Revolyusiya, dalamSovietkiy Soyuæ,Moskwa .

Fennel, J. (1973). Nineteenth Century Russian Literature, Los Angeles: Berkeley, University of California Press.

Fainsod, M. (1958). How Russia Is Ruled,Cambridge : Harvard University Press

Favstov, G.A. (1976). Rossiya Do VelikoiOktyarkoiSocialisticeskoiRevolyutsiidalamSovietkiy Soyuz, Moskwa

Gogol, N.V. (1960). Taras Bulba, Moskwa : Akademia Nauk,SSSR

Gogol, N.V. (1960). Shinel, Moskwa: Akademia Nauk,SSSR.

Geroid, T. (1932). Rural Russia Under The Old Regime, New York

Hartoko, Dick. (1980). GolonganCendekiawenMereka Yang berumah di Angin, PT Gramedia Jakarta.

Harjana, Andre. (1982). KritikSastraSebuabPengantar, Jakarta : PT Gramedia

Jassin, H.B. (1977). TifaPenyairdanDaerahnya, Jakarta. PT GunungAgung

Kleden, Ignas. (1981). KesuastraanTidakHarusMenjadiCerminKeadaanMasyarakat, dalamTifaBudaya, editor Kasijanto\&SapardiDjokoDamono, Jakarta: Leppenas.

Kohn, Hans. (1957). Basic History of Modern Russia, alihbahasaHasjim Jalal Ph.D., Jakarta :Bhratara.

Legg, Keith R. (1983). Tuan, Hamba dan Politisi, Jakarta : Sinar Harapan.

Lenin, V.I. (1932). State and Revolution, New York : International Publishers

Langer, S.K. (1982). PendekatanBaruDalamEstetika, terjemahanA.SudiarjadalamManusiaMulti Dimensional, editor Dr.M.Sastrapratedja, Jakarta :Gramedia.

Mosca, G. (1939). The Ruling Class,Newyork-London

Mashinky, Sergei. (1980). Nikolai Gogol A Selection, Moscow: Progress Publishers.

Pipes, Richard. (1974). Russia Under The Old Regime, New York : Charles Scribper's Sons

Soekito, W. (1969). Manusia, Sastra dan Politik, dalam Sejumlab Masalab Sastra, editor S,Hoerip, Jakarta : Sinar Harapan.

Stumpf, Samuel E. (1975). Karl Marx : Dialectical Materialism dalam Socrates to Sartre: A History of Philosopby U.S.A : McGraw-Hill,Inc. .

Sartre, J.1. (1949). What Is Literature? New fork

Sapir, E. (1949). Language, An Introduction To The Study of Speech, New York

Scholes, R. (1976). Structuralism In Literature, London : Yale University Press.

Slonim, M. (1958). An Outline of Russian Literature, New York and London : Oxford University Press.

Teeuw, A. (1983). MembacadanMenilaiSastra,Jakarta :Gramedia.

Tolstoy, L. (1968). W ar and Peace, translated by Dunnigan London.

Treadgold, W.D. (1973). The West In Russia And China, Cambridge University Press.

Tseitlin. (1963). Zaklyucenyie, dalam Istoriya Russkaya Literatura, ed. Blagoi, D.D., Moskwa: Akademia Nauk SSSR.

Von Rauch, G. (1957). A History of Soviet Russia, New York :Praeger.

Wellek\& Warren. (1956). Theory of Literature, U.S.A. : New Haven, Harcourt, Brace \& World Inc. . 